\title{
FORMULATION AND PHYSICAL PROPERTIES TEST OF NANO CREAM PREPARATION PURIFIED EXTRACT OF KENIKIR LEAF (ETDK) AND TAMPOI FRUIT PEEL EXTRACT (EKBT)
}

\author{
Ika Ristia Rahman*, Sulastri Herdaningsih \\ Yarsi Pharmacy Academy of Pontianak, Jl. Panglima Aim No.2 Pontianak, 78232 \\ Kalimantan Barat, Indonesia \\ *Corresponding author: Ika Ristia Rahman (ika.ristia.apt@gmail.com) \\ Received: 14 June 2021

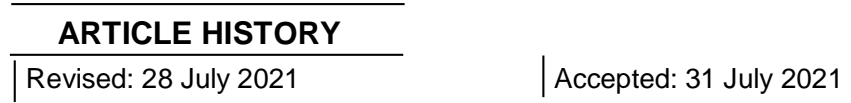

\begin{abstract}
This research has been conducted under the title "formulation and physical properties test of nano cream preparations purified extract of Kenikir leaf (ETDK) and Tampoi fruit peel extract (EKBT)". This study has formulated a nano cream with a purified extract of Kenikir leaf (ETDK), Tampoi fruit peel extract (EKBT), and a combination of ETDK and EKBT. This study aims to determine the purified extract of Kenikir leaves. The purified extract of Tampoi fruit peel can be formulated as nano cream preparations and to determine the physical parameters (organoleptic test, homogeneity, $\mathrm{pH}$, type of nano cream, spreadability, adhesion, and particle size) for the result of the nano cream. The results of the organoleptic test were described and the physical properties of the nano cream were analyzed by using Excel application. Organoleptic testing of the combination of ETDK and EKBT nano cream formula gave a reddish-white color with an aqueous consistency. The ETDK nano cream formula gave a white bone colour with a watery consistency. In contrast, the nano cream formula with EKBT gave a brownish white colour with a watery consistency. It gives a distinctive smell of extract. The third test of nano cream formulas showed that the physical properties of this nano cream preparation met the standard requirements for physical tests. Test the physical properties that meet the $\mathrm{pH}$ requirements, type of nano cream, spreadability, adhesion, and particle size, and all three formulas produced an average particle of less than $300 \mathrm{~nm}$.
\end{abstract}

Key words: kenikir leaf, nano cream, purified extract, tampoi fruit peel.

\section{Introduction}

The use of these plants is still at the level of use for daily fulfilment. Kenikir (Cosmos caudatus) is one of the plants used for vegetables and ornamental plants. Theoretically, it has another potential as raw materials for medicine and cosmetics. Traditionally, Kenikir leaves has been trusted which could increase one's appetite, indigestion, bone strengthening, and insect repellent ${ }^{1}$ Kenikir leaves contain of flavonoids, ${ }^{1,2}$ where the content of the chromophore group can absorb UV light, so that Kenikir leaves have UV protection ability as a sunscreen. ${ }^{3}$ Tampoi fruit belongs to the Baccaurea species group and it is a Tropical fruit with a sweet fresh taste. The Baccaurea species be inspected contain secondary metabolites, including saponins, flavonoids, alkaloids, phenols, anthocyanins, and carotenoids. ${ }^{4,5}$ Research on $^{6}$ The Tampoi bark has antioxidant 
activity, in line with the research ${ }^{7,8}$ which states that Tampoi peel extract has antioxidant activity. The methanol extract of the Tampoi fruit peel contains alkaloid compounds, polyphenols, and flavonoids. The n-hexane fraction contains a group of alkaloid compounds, and the ethyl acetate fraction shows a group of alkaloid and polyphenolic compounds. $^{9}$

Nanotechnology is a technological development that is currently improving. In medicine and cosmetics, nanotechnology is very helpful in drug delivery systems due to the particle size with a nanoscale of $10-1000 \mathrm{~nm}$. The utilization of natural ingredients as raw materials for medicine and cosmetics still tends to be lacking due to natural ingredients such as solubility, adsorbing active substances, low bioavailability, and stability. ${ }^{10}$ These problems were solved by making preparations using nanotechnology methods. The preparations made in this research were creams made by using the nano emulsions method.

Nanocream or nanoemulsion is a topical pharmaceutical preparation that is applied to the skin topically. Nanocream is a drug delivery system consisting of an oil and an aqueous phase combined by a surfactant and cosurfactant. Nanocream has a particle size with a scale of $100-600 \mathrm{~nm} .{ }^{11,12}$ The advantages of nano emulsions are that they can contain many active substances, prevent cracking, creaming because the nanocream dosage form has a large surface area and energy. ${ }^{13}$

This study developed a nano cream formulation from purified Kenikir extract and Tampoi peel extract by using a high-shear stirring method with a mixer. After the nano cream was made, the preparation was tested for physical properties with the parameters of organoleptic test, homogeneity, $\mathrm{pH}$, type of nano cream, spreadability, adhesion, and particle size.

\section{Method}

\section{The Tools}

Some glasswares, digital scales (Shimadzu), a rotary evaporator (Heidolph), a pH meter (handy lab pH), a mixer (Miyako HM-620), Particle Size Analyzer (Horiba SZ-100), a stopwatch, a refrigerator.

\section{The Material}

Purified extract of Kenikir leaf and Tampoi fruit peel extract, $96 \%$ ethanol, n.hexane, ethyl acetate, virgin coconut oil (VCO), Tween 80, PEG 400, aquadest, methylene blue, liquid paraffin.

\section{The Procedure}

\section{The processing of Purified Extract of Kenikir Leaves (Cosmos caudatus Kunth)}

The concentrated extract of Kenikir leaves was dissolved in $35 \mathrm{ml}$ of $50 \%$ ethanol and put in a separating funnel. Then, add $40 \mathrm{~mL}$ of $\mathrm{n}$-hexane. After that, the funnel has shaken continuously, then allowed to stand. After the solution separating into two layers, the ethanol and $n$-hexane layers need to be separated. The dissolution with $n$-hexane need to be repeated till the colour of $n$-hexane layer do not change. Put back the ethanol fraction into the separatory funnel, and add $15 \mathrm{~mL}$ of ethyl acetate solvent, shaken for about 1 minute, and wait for the solution to separate between the purified extract and the ethyl acetate fraction. The separation results are collected and re-condensed to obtain a purified extract. ${ }^{14}$ 


\section{Processing of purified extract of tampoi fruit peel (Baccaurea macrocarpa)}

The thick extract of the Tampoi fruit peel is dissolved with $70 \%$ ethanol and put in a separating funnel; add $50 \mathrm{ml}$ of ethyl acetate to the solution. Until there is a separation and two different layers have formed. Then, separate them.

Table 1. The formula for Nano cream of Kenikir Leaves Furified Extract and Tampoi Fruit Peel Extract.

\begin{tabular}{|c|c|c|c|c|}
\hline \multirow[t]{2}{*}{ Material } & \multicolumn{3}{|c|}{ Formula } & \multirow[t]{2}{*}{ Function } \\
\hline & $\mathbf{I}$ & II & III & \\
\hline $\begin{array}{c}\text { Kenikir Leaves Furified Extract } \\
\text { (gram) }\end{array}$ & 1 & 1 & - & API \\
\hline Tampoi Fruit Peel Extract (gram) & 1 & - & 1 & API \\
\hline VCO (Virgin coconut oil) (gram) & 20 & 20 & 20 & Oil phase \\
\hline TWEEN 80 (gram) & 30,4 & 30,4 & 30,4 & Surfactant \\
\hline PEG 400 (gram) & 7,6 & 7,6 & 7,6 & Co. Surfactant \\
\hline Aquadest (mL) & 40 & 41 & 41 & Water phase \\
\hline
\end{tabular}

The production of purified Extract Nano cream Kenikir Leaves and Tampoi Fruit Peel Extract

The production of nano cream refers to the research of Hermanto 2016, the production of nano cream by using a mixer. The oil phase (VCO, Tween 80 and PEG 400 ) has homogenized by using a mixer for 15 minutes. Add the active substance and mix for 30 minutes. The last, add aquadest and mix for 30 minutes. Then, the nano cream is packaged and ready to be tested for physical parameters.

\section{Physical Properties Test}

Organoleptic

The organoleptic examination includes observation of the texture, the colour, and the odor. The stable nano cream have to show the same character in the same texture, color, and odor.

\section{Homogeneity}

The resulting Nano cream preparation are smeared on a piece of glass and then observed to know whether there are parts that are mixed well or not. The stable nano cream should exhibit a homogeneous arrangement before nor after accelerated storage.

$\mathrm{pH}$ test

The $\mathrm{pH}$ measurement has carried out by using a $\mathrm{pH}$ meter. The calibration conducted by using a standard buffer solution with $\mathrm{pH} 4$ and $\mathrm{pH}$ 7. The $\mathrm{pH}$ of the topical preparation adapted to the $\mathrm{pH}$ of the skin, which are 4, 5-7, to prevent irritation.

Nano cream Type Test

The nano cream type test conducted by dripping methylene blue into the preparation, which placed on a watch glass. A nano cream preparation can have oil in water type $(\mathrm{O} / \mathrm{W})$ or water in oil type $(\mathrm{W} / \mathrm{O})$. The changes in the type of nano cream indicate emulsion instability. ${ }^{15}$

Spreadability Test

The spreadability test conducted by weighing the preparation as much as 0.5 grams and placed on a square glass. Then, the glass covered with another glass. After that, the glass is overwritten with loads of 50,100,150, and 200 grams for 1 minute, the diameter of the dispersion is measured by using a caliper. 


\section{Adhesion Test}

The adhesion test conducted by weighing the preparation as much as 0.25 grams and stored on an object glass. Then, the preparation is overwritten with another object glass. Clamp one of the end of the object glass with a clamp which have added a load of $1 \mathrm{~kg}$. On the other hand, clamp it using a clamp that has been tied to a sturdy object. Then, slowly release it from our hands and count the duration of the separation from both object glasses by using a stopwatch.

Particle size measurement

The test has carried out using a Particle Size Analyzer (PSA) with the Dynamic Light Scattering (DLS) method. The nanoemulsion was filled in a cuvette and entered into the Particle Size Analyzer to measure the droplet size. ${ }^{16}$

The results of the organoleptic testing of the nano cream have been described, the results of the physical properties of the nano cream were analyzed using the Excel application.

\section{Results}

Table 2. The Test Result of Nano Cream Organoleptic of Kenikir Leaves Furified Extract (ETDK) and Tampoi Fruit Peel Extract (EKBT)

\begin{tabular}{ccccc}
\hline FORMULA & Colour & $\begin{array}{c}\text { Organoleptic } \\
\text { Flavour }\end{array}$ & Consistention & Homogenity \\
\hline $\begin{array}{c}\text { Nano cream } \\
\text { combination }\end{array}$ & Reddish white & $\begin{array}{c}\text { Extract } \\
\text { typical }\end{array}$ & watery & Homogeneous \\
$\begin{array}{c}\text { ETDK+EKBT } \\
\text { Nano cream }\end{array}$ & Bone & $\begin{array}{c}\text { Extract } \\
\text { typical }\end{array}$ & thick & Homogeneous \\
$\begin{array}{c}\text { ETDK } \\
\text { EKBT }\end{array}$ & Brownish white & $\begin{array}{c}\text { Extract } \\
\text { typical }\end{array}$ & thick & Homogeneous \\
\hline
\end{tabular}

Description:

ETDK = Kenikir Leaves Furified Extract

$E K B T=$ Tampoi Fruit Peel Extract

Table 3. The Result Test of Physical Properties Of EDTK and EKBT Nano Creams

\begin{tabular}{lccccc}
\hline \multicolumn{1}{c}{ Formula } & $\begin{array}{c}\text { Adhesion } \\
\text { (seconds) }\end{array}$ & $\begin{array}{c}\text { Spreadability } \\
\text { (cm) }\end{array}$ & pH & $\begin{array}{c}\text { Emulsion } \\
\text { type }\end{array}$ & $\begin{array}{c}\text { Particle } \\
\text { size (nm) }\end{array}$ \\
\hline $\begin{array}{l}\text { Nano cream } \\
\text { combination }\end{array}$ & $40.73 \pm 1.10$ & $4.63 \pm 0.31$ & $4.44 \pm 0.05$ & O/W & 283,5 \\
$\begin{array}{l}\text { ETDK+EKBT } \\
\begin{array}{l}\text { ETDK Nano } \\
\text { cream }\end{array}\end{array}$ & $40.00 \pm 2.00$ & $4.47 \pm 0.32$ & $6.05 \pm 0.03$ & O/W & 292,5 \\
$\begin{array}{l}\text { EKBT Nano } \\
\text { cream }\end{array}$ & $39.67 \pm 1.53$ & $4.37 \pm 0.32$ & $4.32 \pm 0.01$ & O/W & 289,6 \\
$\begin{array}{l}\text { Description: } \\
\begin{array}{l}\text { ETDK }=\text { Kenikir Leaves Furified Extract } \\
\text { EKBT }=\text { Tampoi Fruit Peel Extract }\end{array}\end{array}$ & & & & \\
\end{tabular}




\section{Discussion}

Kenikir leaf fertilized extract (ETDK) and tampoi fruit peel extract (EKBT) nano cream made by using high-energy emulsification method of high-shear stirring because they were made by using a mixer that has a rotary motor system. The procedure of making the nano cream refers to the production of piroxicam nano cream which carried out by Abdulkarim et al., in 2010 with different materials, active substances, and the tools. However, for the tools, both of production were using rotary motor systems. Nano cream has been made by ${ }^{17}$ using the low energy method (EIP) using a modified magnetic stirrer with electrodes and produced KAD nano cream with a droplet size of $<350 \mathrm{~nm}$. The production of nano cream using the active substance of Kenikir leaves and Tampoi fruit peel which contains of antioxidants.

In this study, the purification of the extract obtained was carried out. The purification had been carried out to remove secondary non-metabolic compounds such as resins, sucrose, fats, carbohydrates (polysaccharides), and others that can interfere with the secondary metabolite activity of Kenikir leaves. The purification process is a method to obtain components of purely natural ingredients free from other chemical components which are not needed. ${ }^{18,19}$ The purification method which has been used was liquid partition by using a separating funnel because the tool and the processing method are relatively simple. Specifically, there are two types of solvents that do not mix. The purification of the Kenikir leaf extract was made by using two kinds of solvents, namely n-hexane (non polar) and ethyl acetate (semi polar).

The concentrated extract of kenikir leaves was weighed about $15 \mathrm{~g}$ and it diluted with $35 \mathrm{ml}$ of $50 \%$ ethanol. The dilution of the thick extract with $50 \%$ ethanol aims to maximize the withdrawal of secondary metabolite and make the solution more separated optimally. The diluted extract has been put into a separating funnel mixed with $40 \mathrm{ml}$ of $\mathrm{n}$-hexane. Then, it has been shaken until the solution between the purified extract and the $n$-hexane fraction separated. The purpose of using $n$-hexane is to attract chlorophyll compounds present in the extract, which are considered ballast substances or impurities in this study.

The purified extract was put back into the separating funnel and it was added $15 \mathrm{ml}$ of ethyl acetate. The shaking was carried out for about 1 minute and the result of the shaking were allowed to stand until the purified extract and the ethyl acetate fraction were separated. The purpose of using ethyl acetate is to attract fat and wax compounds in the extract and to clean the content of other semi-polar chemical compounds, ${ }^{19}$ which are considered ballast substances or impurities in this study. The results of the purification are then evaporated on the back of the bath. The purpose of this evaporation is to thicken the extract and remove the solvent used during the purification process.

The preparation can be declared has quality if it meets the criteria for physical properties and can maintain during storage (stable). Physical properties tests were include organoleptic properties, homogeneity, $\mathrm{pH}$, type of nano cream, viscosity, dispersion and adhesion of nano cream.

Organoleptic tests carried out included physical observations of the odor, the colour, and the consistency of nano cream. The acceptance of use and aesthetic value of a product can be seen from organoleptic tests. The organoleptic test was carried out by observing the preparation directly by using the body's organs. The results of organoleptic tests on kenikir leaf fertilized extract and tampoi fruit peel extract nano creams showed that the nano cream had a characteristic odor of the extract. The combination of kenikir leaf fertilized extract and tampoi fruit peel extract nano cream formula gives a reddish-white preparation, the kenikir leaf fertilized extract nano cream formula gives a bone white colour while the tampoi fruit peel extract nano cream formula gives a brownish white colour. The consistency of the nano cream with the combination of kenikir leaf fertilized extract and tampoi fruit peel extract gave a runny consistency, 
while the kenikir leaf fertilized extract nano cream and tampoi fruit peel extract nano cream gave a thick consistency.

The homogeneity test was carried out to ensure that all of the ingredients in the nano cream were homogeneously mixed so that they have the same dose when used. The homogeneity test measurement is based on visual observation of the particle distribution. The observation of the kenikir leaf fertilized extract and tampoi fruit peel extract nano creams showed that the nano cream made was homogeneous because it had evenly distributed particles and did not experience agglomeration.

The value of adhesion is the value that indicates to the ability of the preparation could adhere to the site of application. The cream could be declared good if the adhesion value is more than 4 second. ${ }^{20,21}$ The longer the time produced in the adhesion test, then, the longer the contact of the cream on the skin, which causes more absorption of the active substance. All three formulas provide adhesion more than 4 seconds.

A spreadability test was carried out to determine the spread of nano cream when used. Well-dispersed nano cream will affect the absorption of the skin so that it will affect the absorption and absorption of the active substance. The results of the dispersion test of the three formulas had good dispersion because they were following the criteria for the spreadability of the cream, which was less than $5 \mathrm{~cm}$ to $7 \mathrm{~cm}$ in diameter. The dispersion of kenikir leaf fertilized extract and tampoi fruit peel extract nano cream has a diameter in the range of 4.37-4.67 under $5 \mathrm{~cm}$.

As a topical preparation, nano cream should have the same $\mathrm{pH}$ as the skin $\mathrm{pH}$, which is between 4.5 to 7 to prevent skin irritation caused by differences in $\mathrm{pH}$. Kenikir leaf purified extract nano cream (ETDK) has a pH value of 6.05. The value for tampoi fruit peel extract nano cream (EKBT) is $4.32 \mathrm{pH}$. Meanwhile the value for nano cream with a combination of kenikir leaf fertilized extract and tampoi fruit peel extract is $4.4 \mathrm{pH}$. In the combination extract formulation, there was a change in $\mathrm{pH}$ due to the $\mathrm{pH}$ of the tampoi fruit peel extract which was more acidic than the purified extract of kenikir leaves. However, the $\mathrm{pH}$ values of the three formulas were still in the skin $\mathrm{pH}$ range. However, the $\mathrm{pH}$ values of the three formulas were still in the skin $\mathrm{pH}$ range. Preparations with an appropriate $\mathrm{pH}$ value range will minimize irritation due to too acidic or too alkaline $\mathrm{Ph} .{ }^{22}$

The nano cream type test has been used to determine whether the type of nano cream made was suitable to make nano cream. The nano cream type test was carried out with a methylene blue solution as an indicator and observed. Methylene blue is soluble in water and insoluble in oil. If the methylene blue is evenly distributed, the nano cream is of the W/A type, and vice versa. From the experimental results, methylene blue was evenly distributed so that the three formulations were of type M/A. It's in line with Hermanto's research in 2016 with the basic which used for nano cream type with M/A type result. ${ }^{23}$

The nano cream droplet size was measured using the Dynamic Light Scattering (DLS) method using a Particle Size Analyzer (PSA). The resulting droplet size, influenced by the equipment used, temperature, time, and materials. ${ }^{13,24}$ The results of the droplet size test of the three formulas produced an average particle of less than $300 \mathrm{~nm}$. The formula with the combination of kenikir leaf fertilized extract and tampoi fruit peel extract nano cream gave a particle size of $283.5 \mathrm{~nm}$, the procedure with extract kenikir leaf fertilized extract gave a particle size of $292.5 \mathrm{~nm}$. The formula with tampoi fruit peel extract gave a particle size of $289.6 \mathrm{~nm}$. all three formulations show that the droplet size was classified as nano cream size, which is in the range of $100-600 \mathrm{~nm}{ }^{11,12}$ 


\section{Conclusion}

Purified extracts of kenikir leaves and tampoi fruit peel extracts can be formulated into nano cream preparations. The three formulas that has been made were meet the physical requirements. The physical requirements $\mathrm{pH}$ requirements, type of nano cream, spreadability, adhesion, and particle size, and all three formulas produced an average particle of less than $300 \mathrm{~nm}$. They have met the requirements of a good nano cream.

\section{Acknowledgments}

I would like to thank the Indonesian Ministry of Education and Culture/ RISTEK DIKTI for funding this research. I also would like to thank Yarsi Pharmacy Academy of Pontianak for all of the support.

\section{Bibliography}

1. Andarwulan N, Kurniasih D, Apriady RA, Rahmat $H$, Roto AV, Bolling BW. Polyphenols, carotenoids, and ascorbic acid in underutilized medicinal vegetables. $J$ Funct Foods [Internet]. 2012;4(1):339-47. Available from: http://dx.doi.org/10.1016/j.jff.2012.01.003

2. Cheng SH, Khoo HE, Ismail A, Abdul-Hamid A, Barakatun-Nisak MY. Influence of extraction solvents on Cosmos caudatus leaf antioxidant properties. Iran J Sci Technol Trans A Sci. 2016;40(1):51-8.

3. Whenny, Rusli Rolan RL. Aktivitas tabir surya ekstrak daun cempedak (Artocarpus Champeden Spreng). J Sains dan Kesehat. 2015;1(4):154-8.

4. Abu Bakar MF, Ahmad NE, Karim FA, Saib S. Phytochemicals and antioxidative properties of borneo indigenous liposu (Baccaurea lanceolata) and tampoi (Baccaurea macrocarpa) fruits. Antioxidants. 2014;

5. Tirtana E, Idiawati N, Warsidah, Jayuska A. ISSN 2303-1077. Analisa proksimat, uji fitokimia dan aktivitas antioksidan pada buah tampoi (Baccaurea macrocarpa). J Kim Khatulis. 2013;2(1):42-5.

6. Novitaria $\mathrm{B}$, Alimuddin AH, Destiarti L. Isolasi dan karakterisasi golongan senyawa fenolik dari kulit batang tampoi (Baccaurea macrocarpa). J Kaji Komun. 2016;5(2):27-32.

7. Erwin E, Pusparohmana WR, Sari IP, Hairani R, Usman U. Phytochemical and antioxidant activity evaluation of the bark of Tampoi (Baccaurea macrocarpa) F1000Research. 2018;7:1-9.

8. Erwin E, Pusparohmana WR, Sari IP, Hairani R, Usman U. GC-MS profiling and DPPH radical scavenging activity of the bark of Tampoi (Baccaurea macrocarpa). F1000Research. 2019;7:1977.

9. Yunus R, Alimuddin HA, Ardiningsih P. Uji aktivitas antibakteri ekstrak kulit buah tampoi (Baccaurea Macrocarpa) terhadap bakteri escherichia coli dan staphylococcus aureus. J Kaji Komun. 2014;3(3):19-24.

10. Hanutami B, Budiman A. Penggunaan Teknologi Nano Pada Formulasi Obat Herbal. Farmaka. 2017;15:29-39.

11. Zainol NA, Ming TS, Darwis Y. Development and characterization of cinnamon leaf oil nanocream for topical application. Indian J Pharm Sci. 2015;77(4):422-33.

12. Sonje A, Thube R, Parmar V, Kumari G, Deshpande P. A review on penetration enhancer for semisolids. Asian J Pharm Res Dev [Internet]. 2013;1(5):94-107. Available from: www.ajprd.com 93

13. Jusnita N, Tridharma WS. Karakterisasi nanoemulsi ekstrak daun kelor (Moringa 
oleifera Lamk.). J Sains Farm Klin. 2019;

14. Hospita K, Berefek LY. Formulasi dan uji stabilitas sediaan gel ekstrak terpurifikasi daun paliasa (Kleinhovia Hospita L.) yang berefek antioksidan. Pharmacon. 2017;6(3):157-69.

15. Abdulkarim MF, Abdullah GZ, Chitneni M, Mahdi ES, Yam MF, Faisal A, et al. Stability studies of nano-cream containing piroxicam. Int $\mathrm{J}$ Drug Deliv. 2010;2(4):333-9.

16. Juniatik M, Hidayati K, Wulandari FP, Pangestuti N, Munawaroh N, Martien R, et al. Formulation of nanoemulsion mouthwash combination of lemongrass oil (Cymbopogon citratus) and kaffir lime oil (Citrus Hystrix) for anticandidiasis against candida albicans ATCC 10231. Tradit Med J. 2017;22(1):7-15.

17. Al-Edresi S, Baie S. In-vitro and in-vivo evaluation of a photo-protective kojic dipalmitate loaded into nano-creams. Asian J Pharm Sci. 2010;5(6):251-65.

18. Nurjannah F. Pengaruh pelarut puriikasi terhadap kadar fenolik total ekstrak biji kopi hijau arabika (Coffe arabica L.). Skripsi. 2020;(Agustus):Universitas Nadi waluyo, Semarang.

19. Januarti IB, Wijayanti R, Wahyuningsih S, Nisa Z. Potensi ekstrak terpurifikasi daun sirih merah (Piper crocatum Ruiz \&Pav) sebagai antioksidan dan antibakteri. JPSCR J Pharm Sci Clin Res. 2019;4(2):60.

20. Garg A, Aggarwal D, Garg S, Singla AK. Spreading of semisolid formulations: An update. Pharm Technol North Am. 2002 Sep 1;26:84-105.

21. Indratmoko $S$, Nurmayadah $H$, Nurwahidah AT. Pengembangan Formula krim nanosqualene cream formula development with tween 80 and PEG 400 combinations. Borneo J Phamascientech. 2019;03(02):160-8.

22. Destiyana OY, Hajrah, Rijai L. Formulasi nanoemulsi kombinasi ekstrak bunga mawar (Rosa damascena Mill.) dan ekstrak umbi bengkuang (Pachyrhizus erosus L.) menggunakan minyak pembawa virgin coconut oil (VCO). Proceeding Mulawarman Pharm Conf [Internet]. 2018 Dec 31;8(1 SE-Articles). Available from: https://prosiding.farmasi.unmul.ac.id/index.php/mpc/article/view/331

23. Hermanto VC. Pembuatan nanokrim kojic acid dipalitate dengan kombinasi surfaktan tween 80 dan kosurfaktan propilen glikol 400 menggunakan mixer. Skripsi. 2016;Universitas Sanata Darma, Yogyakarta.

24. Lee SJ, McClements DJ. Fabrication of protein-stabilized nanoemulsions using a combined homogenization and amphiphilic solvent dissolution/evaporation approach. Food Hydrocoll [Internet]. 2010;24(6):560-9. Available from: https://www.sciencedirect.com/science/article/pii/S0268005X10000238 